\title{
Fossil hunters bristle over plans for US tour
}

Rex Dalton, San Diego

She may be 3.2 million years old, but plans are being laid to send Lucy on her first vacation. A museum in Texas is negotiating a deal to bring the skeleton of the famous hominid from Ethiopia to the United States for its public debut.

But the idea of transporting the fossil as opposed to a replicate cast - from east Africa for a three-year travelling exhibition is raising some eyebrows.

Concerned about the exploitation of poorer countries and possible damage to valuable specimens, palaeoanthropologists from 20 nations agreed in 1999 to oppose the transportation of original fossils in travelling exhibitions. The policy, published by the International Association for the Study of Human Paleontology, recommends that "original hominid fossils should not be transported beyond the country of origin, unless there are compelling scientific reasons" for the journey. The International Association of Human Biologists also adopted the policy.

Lucy's original skeleton (Australopithecus afarensis) is housed in a vault in the National Museum of Ethiopia in Addis Ababa, where a cast of it is publicly displayed. But under a plan backed by politicians and business leaders in Houston, Texas, and in Ethiopia, the Houston Museum of Natural Science would put the real skeleton on show from 2006.

The exhibition has been conceived to help build business and cultural links between Texas and Ethiopia. On a trip to Addis Ababa in April, a delegation from Texas met with senior government officials, including the president, Girma Wolde-

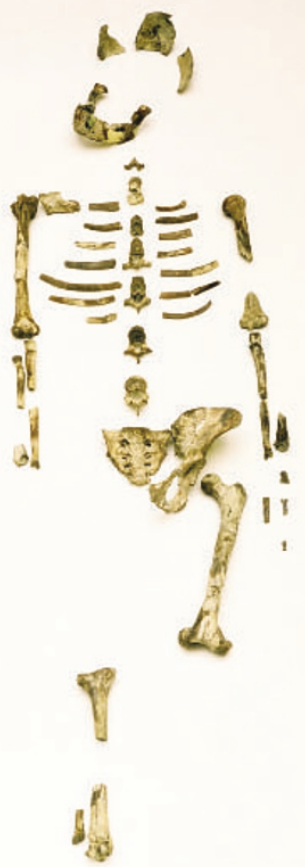

Dead cert? The original remains of Lucy could be the star attraction in a travelling exhibition.

Giorgis, and obtained a letter of intent from the Ethiopian Tourism Commission that the tour should take place.

But some fossil experts are unhappy with the plan. "I don't think original fossils should be moved without good scientific reason," says Bernard Wood, a palaeoanthropologist at George Washington University in Washington DC who signed the 1999 policy. Wood, however, concedes that a lucrative series of US exhibitions could help the
Ethiopian museum. "African museums are badly underfunded," he says, adding that the exhibition could be justified if enough of the proceeds go back to the museum in Addis Ababa. The terms of the proposed deal have not yet been negotiated.

Alan Parrish, interim president of the Houston museum, says that he wasn't familiar with the palaeontology association's policy. "We are aware that there is controversy on the transportation of early artefacts," he says, adding that the exhibition will be planned with appropriate care, security and reverence, and will be "good for Ethiopia".

The exhibition would include a range of Ethiopian artefacts and fossils - but the $40 \%$-complete skeleton of Lucy would be its centre-piece. The skeleton was found in 1974 at Hadar by Donald Johanson, now of the Institute of Human Origins at Arizona State University in Tempe. He declined to comment on the exhibition plans.

Anthropologist Mamitu Yilma, director of the Ethiopian museum, says that the agreement is currently "only a letter of understanding". She adds that "it is not yet decided" if the original Lucy will go on tour. Yilma declined to give a view on it doing so.

But Zeresenay Alemseged, an Ethiopian palaeoanthropologist now at the Max Planck Institute for Evolutionary Anthropology in Leipzig, Germany, said: “I can't support the exhibit. I want to know more about security and the handling of the fossils."

Houston museum officials hope to finalize arrangements in the next few months, with a possibility that they may join forces with another major museum in the eastern United States to advance their bid.

\section{Scientists deny ethical breach at Kenyan orphanage}

\section{Declan Butler}

British researchers are hotly contesting allegations that they short-circuited ethical procedures in research involving children at the Nyumbani orphanage in Nairobi, Kenya.

The centre has attracted international interest because some of the children there who have AIDS seem to control their HIV infection without drug therapy, and survive beyond their expected lifespan with a relatively intact immune system.

On 23 May, the Nairobi-based Sunday Nation ran a story under the headline "Shame of children used in experiments on Aids". In it, the paper alleged that Eric Miller, a researcher from the University of Cambridge, carried out research at the orphanage in April without government approval. It also claimed that a group from the University of Oxford that visited the centre in 2001 had exported blood samples without permission.

Kenya's National Council for Science and Technology is looking into the allegations. But Ababu Namwamba, a lawyer representing the orphanage, says that the allegations are groundless and originate from a disgruntled former employee. In a statement prepared by Namwamba, the centre says that Miller did no research and only visited the orphanage "on a fact-finding mission" with a view to future research on the impact of food supplements on HIV progression.

The Oxford group's work, which resulted in two research papers, received ethical clearance from the national council on 8 January 2001, according to the centre. It admits that the original proposal omitted to request specific consent to send samples to Oxford, but says that once this oversight was spotted, Nyumbani and the university immediately told the council, and got ethical approval in September 2002.

In a letter addressed to the Nation last week, the Oxford researchers involved, Sarah Rowland-Jones and Rana Chakraborty from the Medical Research Council's Human Immunology Unit, added that once they had discovered the discrepancy, they "called an immediate halt to all research and export of samples until the matter could be cleared up".

The orphanage says that it "experienced the spreading of malicious propaganda", after it fired a scientist in 2001. It adds that it wants the government to investigate the matter so that it can clear its name. 